\title{
Recent Sightings of the Malabar Toad, Duttaphrynus hololius (Günther 1876), from Tamil Nadu, India
}

\author{
M. Rameshwaran ${ }^{1}$ and Amit Sayyed ${ }^{2}$
}

${ }^{1}$ Reptile Conservation of India (RCI), No: 9/98, Dr. Chelladurai Nagar, Krishnapuram, Tirunelveli - 627 011,Tamil Nadu, India (mrameshwaran@gmail.com) ${ }^{2}$ Wildlife Protection and Research Society, 40, Rajaspura Peth, Satara, Maharashtra 415002, India (corresponding author: amitsayyedsatara@gmail.com)

T he Malabar Toad, Duttaphrynus hololius (Günther 1876), also known as Günther's Toad (Fig. 1), is a rare Indian endemic (Biju et al. 2004). Recent studies (Satyamurthi 1967; Thurston 1888; Pillai and Ravichandran 1991; Daniels 1992; Chandramouli et al. 2011; Adimallaiah et al. 2012; Kalaimani et al. 2012; Srinivasulu et al. 2013) cited records from Vishakhapatnam, Nellore, and Chittoor in Andhra Pradesh; from Nalgonda, Telangana, Krishnagiri, Villupuram, and two sites at Vellore in Tamil Nadu; and from Bannerghatta and Ramanagara in Karnataka; all are in the Eastern Ghats. Herein, we document a new southernmost locality in Tamil Nadu (Fig. 2).
On 24 October 2013, MR visited the historic Chithannavasal $\left(10^{\circ} 27^{\prime} 59.53^{\prime \prime} \mathrm{N}, 7^{\circ} 44^{\prime} 0.42 " \mathrm{E}\right.$; elev. 127 m), Pudukkottai District, Tamil Nadu. At about 1810 h, he encountered seven toads on rock boulders near the stairs and on the rock wall near naturally flowing water. Considerable rain had fallen two days prior to this sighting. Subsequently, at $1800 \mathrm{~h}$ on 14 February 2014, a return to the site revealed no toads. The surrounding grassy area had burned. Again, on 12 September 2017, both authors visited the site and encountered four toads at about $1830 \mathrm{~h}$ near puddles and in grassy patches. The toads were examined (not collected) and identified as Duttaphrynus hololius. We also saw Common

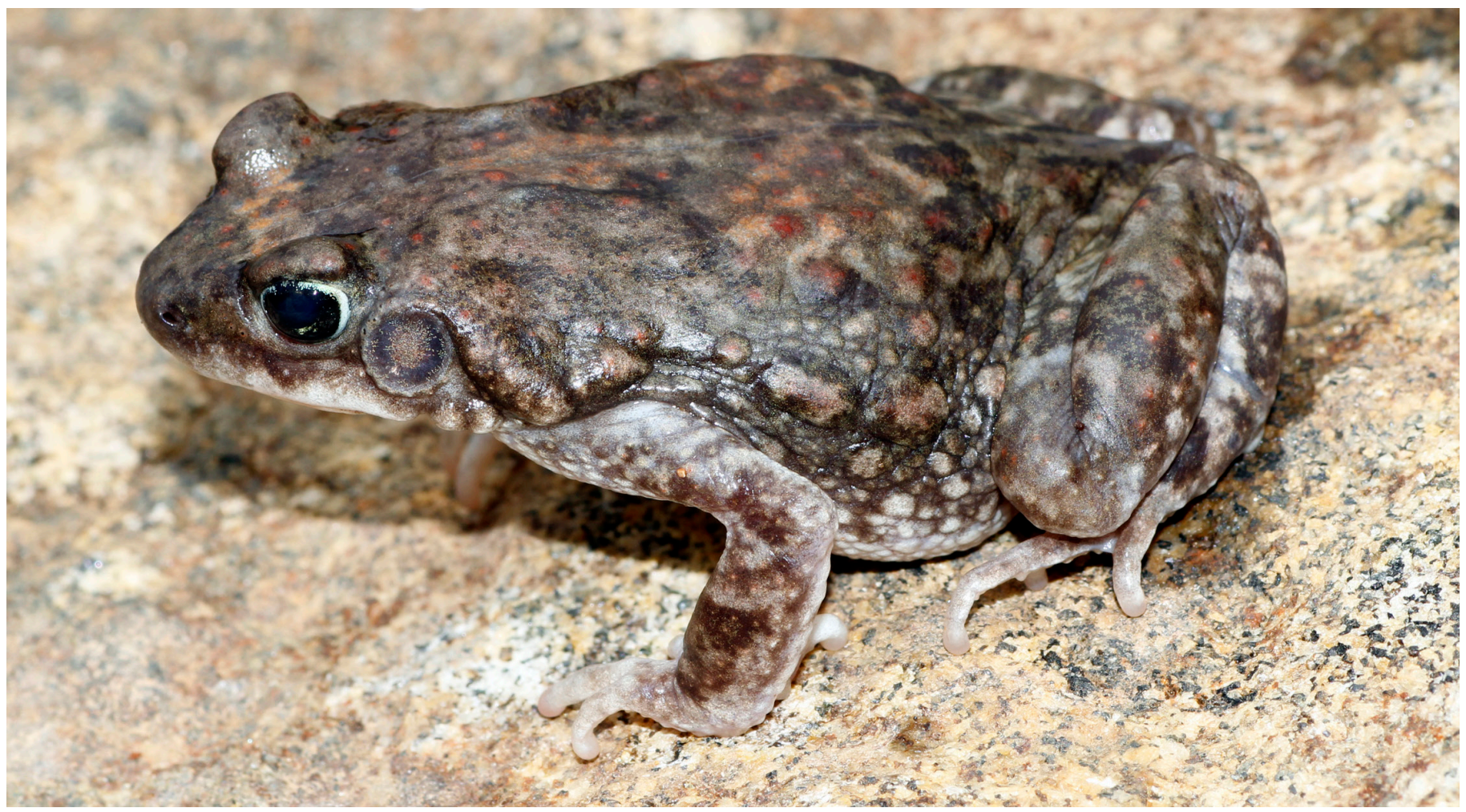

Fig. 1. A Malabar Toad (Duttaphrynus hololius) encountered at Chithannavasal, Pudukkottai District, Tamil Nadu. Photograph by M. Rameshwaran. 


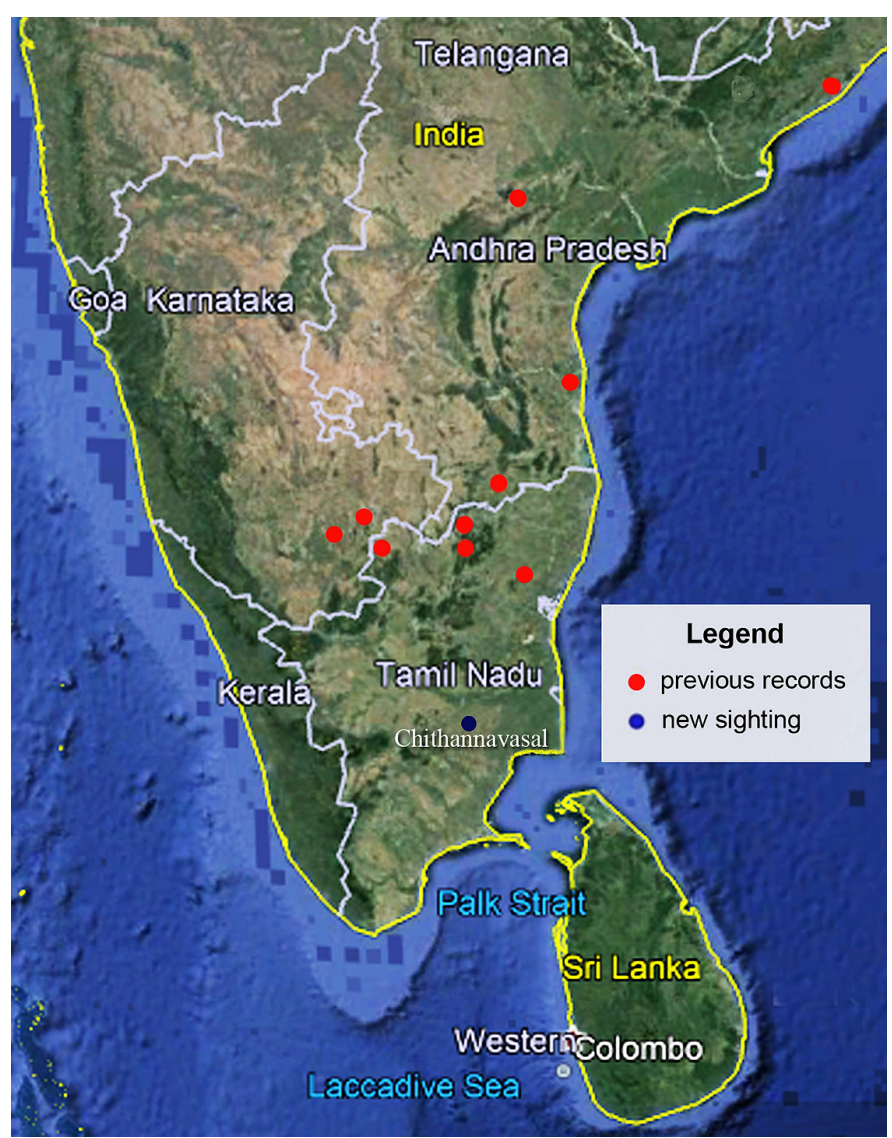

Fig. 2. Map of peninsular India showing the distribution of the Malabar Toad (Duttaphrynus hololius).
Indian Treefrogs (Polypedates maculatus) and Five-fingered Frogs (Euphlyctissp.). Habitat in the area (Fig. 3) is a boulderstrewn mountain slope with thorny scrub, small to mediumsized trees, grassy patches, and shallow puddles. Uncontrolled tourism and fires started inadvertently (or intentionally) likely pose substantive threats to this population.

\section{Acknowledgements}

We are thankful to the Archaeological Survey of India (ASI), Government of India, Tamil Nadu; the Forest Department of Tamil Nadu; and Mr. K. Ramnath Chandrasekar, Co-Founder, Youth for Conservation (YFC), for help in the field; and to Mr. Brawin Kumar for his constant encouragement of MR.

\section{Literature Cited}

Adimallaiah, D., V.V. Rao, and G. Surender. 2012. Report of Günther's Toad Duttaphrynus hololius (Günther, 1876) from Nalgonda District, Andhra Pradesh. Cobra 6: 8-11.

Biju, S.D., S. Dutta, K. Vasudevan, S.P. Vijayakumar, C. Srinivasulu, and G. Dasaramji Buddhe. 2004 (errata version published in 2016). Duttaphrynus hololius. The IUCN Red List of Threatened Species 2004: e.T54665A86102727 (http://www.iucnredlist.org/details/54665/0).

Chandramouli, S.R., S.R. Ganesh, and N. Baskaran. 2011. On recent sightings of a little known toad, Duttaphrynus hololius (Günther, 1876) with notes on its morphological characterization and ecology. Herpetology Notes 4: 271-274.

Daniels, R.J.R. 1992. Range extension in some south Indian amphibians. Hamadryad 17: 40-42.

Kalaimani, A., A. Nath, and R.B. Kumar. 2012. A note on the records of rare and endemic Duttaphrynus hololius (Günther, 1876). Frog Log 18: 27-30.

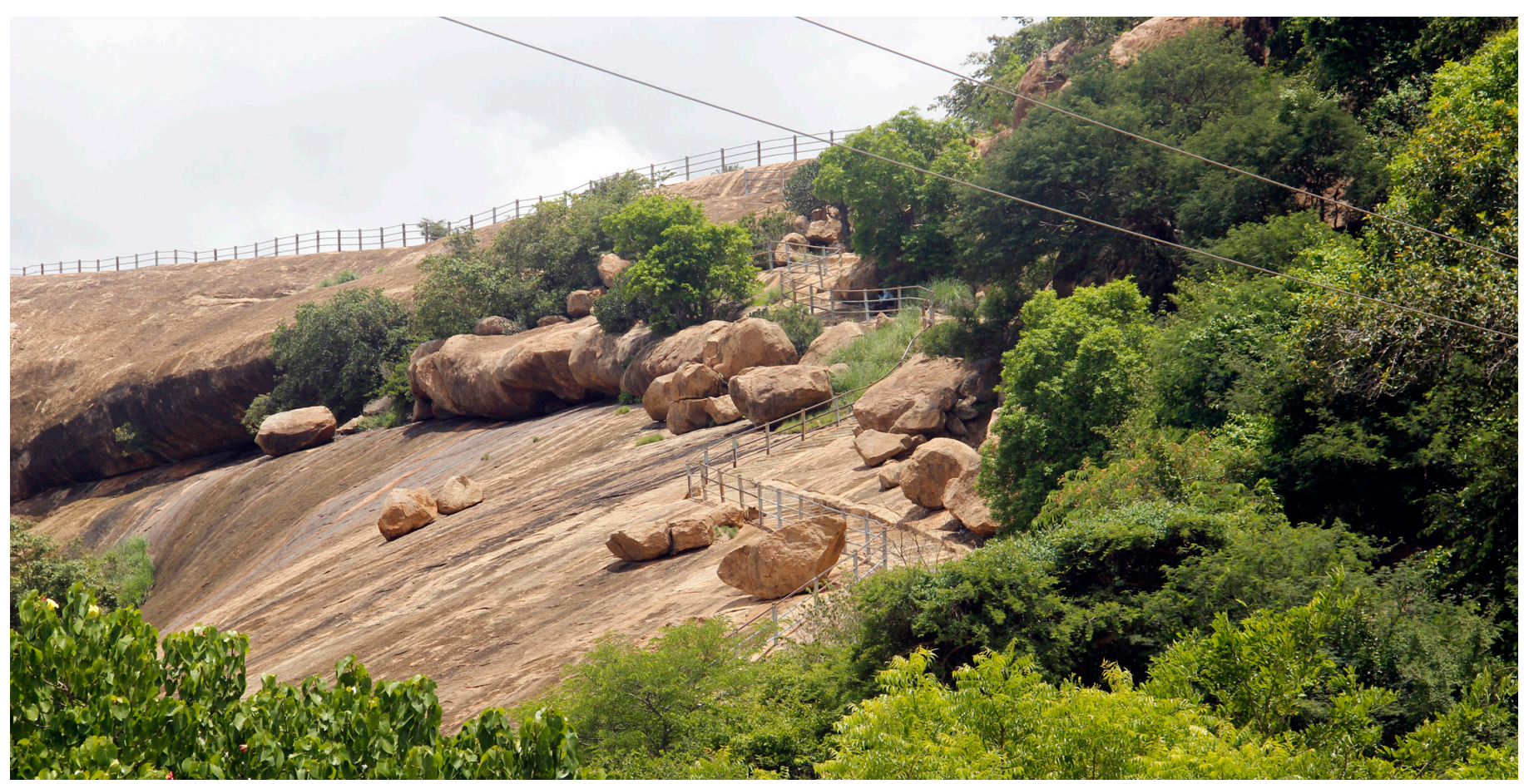

Fig. 3. Habitat at Chithannavasal, Pudukkottai District, Tamil Nadu where Malabar Toads (Duttaphrynus hololius) were encountered. Photograph by M. Rameshwaran. 
Pillai, R.S. and M.S. Ravichandran. 1991. On a rare toad Bufo hololius Günther from Nagarjunsagar, Andhra Pradesh. Records of the Zoological Survey of India 88: 11-14.

Satyamurti, S.T. 1967. The South Indian Amphibia in the Collection of the Madras Government Museum. Madras Government Museum, Madras, India.

Srinivasulu, B., S.R. Ganesh, and C. Srinivasulu. 2013. New regional record and notes on historical specimens of Günther's Toad Duttaphrynus hololius with comments on other southeastern Indian congeners. Journal of Threatened Taxa 5: 4784-4790.

Thurston, E. 1888. Catalogue of Batrachia, Salientia and Apoda (Frogs, Toads and Coecilians) of Southern India. The Superintendent, Government Press, Madras, India. 